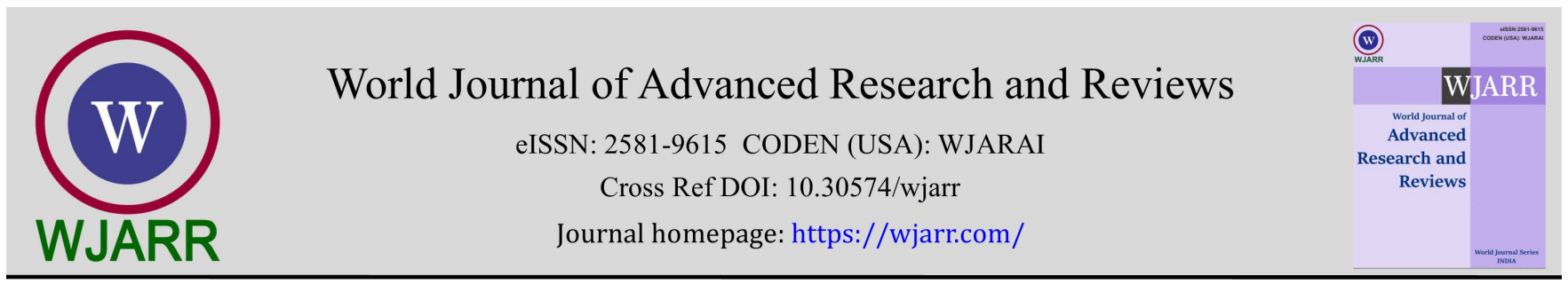

(CASE REPORT)

\title{
Situation of older women living at Slum area in Dhaka City of Bangladesh
}

\author{
Mousumi Adhikary 1, ${ }^{*}$, Sanjib Chandra Mandal 2, Urme Nag ${ }^{3}$, Fuzael Ahmed 4 \\ ${ }^{1}$ BIRDEM Nursing College, Dhaka, Bangladesh. \\ ${ }^{2}$ Centre for the Rehabilitation of the Paralysed (CRP), Dhaka, Bangladesh. \\ 3250 bedded General Hospital, Anderkilla, Chattagram, Bangladesh. \\ ${ }^{4}$ Agrani Bank Ltd., [Golapgonj, Sylhet, Bangladesh.
}

World Journal of Advanced Research and Reviews, 2021, 11(02), 285-290

Publication history: Received on 24 May 2021; revised on 15 August 2021; accepted on 17 August 2021

Article DOI: https://doi.org/10.30574/wjarr.2021.11.2.0295

\begin{abstract}
The older section of the population is increasing much faster than the total population. Older women bear a disproportionately low status in every aspects of life in Bangladesh. They have less control over their family income and family decision making. The objective of this study was to find out the situation of older women living at slum area. This is a descriptive data where data were collected from Dhaka city Bangladesh in slum area. In Bangladesh many older people spend their lives in poverty and ill health which is major risk for the elderly population. Poverty and exclusion are the greatest threats to the wellbeing of older people. They passed their very basic QoL with no proper humanitarian support. The policy maker should take the proper steps for improving their QoL as well as think about their basic rights.
\end{abstract}

Keywords: Older women; QoL, Dhaka city; Slum area; Bangladesh

\section{Introduction}

Bangladesh is one of the most populated countries in the world. The total population of Bangladesh is approximately 16.37 million with a growth rate 1.57 per cent (BDP, July 2013). About $60 \%$ of the populations in Dhaka city are migrants where more than $65 \%$ of the people live in slum areas. There are 9048 slums in six division city of Bangladesh which are 75\% situated in Dhaka city (The Daily Star Forum: July, 2012). Here most of the people are older women. The physical condition of slums is characterized by high density living, improper utilization of public goods, lack of basic amenities, unhygienic and polluted environment, poor literacy rate, unemployment, crime, social, moral and psychological degradation and poor health (Alamgir et al. 2009). Elderly dependency rate is 7.3 \% (BDP, July 2013). Among them elderly women are more vulnerable due to social and economic marginalization (Ferdous et al. 2009). In China Zang, Li, and Feldman (2005) found that elder women lack control over financial resources. Older people's health may also be compromised by poor diet and nutrition (Carr, 2012). This is especially true for older women. (Rahman, et al. 2007). However, due to rising population, the number of slum dwellers is rising. One billion people worldwide live in slums and the figure will likely grow to 2 billion by 2030. The urban poor generally live in slums or on the streets. Exposure to polluted air, contaminated water and food, and inadequate facilities for regular physical activity presents acute and chronic disease hazards. Crime and violence rates may be higher, with women and children at high risk. In slums across the world, there is a noticeable lack of basic infrastructure, services, and basic shelter.

\section{Methods}

This is a descriptive method where data were collected through case by case face to face interviewing the patients. Data were collected from a slum area of Malek Bosti at Kamrangir Chore and Karom Alli Bosti at Agargaon in Dhaka City of

\footnotetext{
${ }^{*}$ Corresponding author: Mousumi Adhikary

BIRDEM Nursing College, Dhaka, Bangladesh.
}

Copyright (C) 2021 Author(s) retain the copyright of this article. This article is published under the terms of the Creative Commons Attribution Liscense 4.0. 
Bangladesh. Most the sample age were above 60 years and especially older women. Data were collected from April and May, 2014.

\section{Case Studies}

\subsection{Case: 1}

The case- 1 respondent's is 85 years widow women lives in Karom Alli Bosti at Agargaon with her divorcee daughter and two grandchildren. She could only signature. She has migrated with her family from Manikgonge for better living about 43 years ago. The respondent is fully dependent on her daughter's income. Her daughter is a day laborer and she sometimes earns 3,000 or 3,500 tk per month. It's very difficult to maintain family expenditure and manage basic needs. She lives in a single tin shade room divided into two parts which is also surrounded by tin and floor is damped. All of them sleep on the floor. She got electricity but use only one light because she hasn't ability to buy a fan. They have no standard toilet and bathroom. They have no water supply line. They buy water for everyday use even for bath. They use a separate kitchen which is attached with their room. She gets old age allowance from government 300 tk per month. She is not a healthy person and suffers from different types of old age related disease such as chest pain, arthritis, visual problem, dementia, depression and high presser etc. The respondent goes to near hospital when she feels very sick and she has no ability to buy full medicine. Her sleeping is not regular and sometimes she can't sleep at night because of tension. She spends her leisure time by gossiping with neighbors and watches television of neighbors.

\subsection{Case: 2}

Respondent- 2 age is 70 years widow women, lives at Karam Ali Boste, Agargaon, Dhaka and she came from Syllet alone with her daughter \& son. She has no educational qualification. She lives in a small room with her daughter from last 1 year. Her daughter used to work as maid servant. The floor of the room is made with wood above small canal, the wall \& roof is in tin. She spends all day working in household \& takes care of her grandchildren. She spends her leisure time by gossiping with neighbor \& praying. Her daughter takes care of her if she is sick. She depends on her daughter to meet her basic needs. Psychologically she is feeling insecure \& helpless. She is suffering from loneliness, depression \& insomnia respiratory distress due to bronchial asthma \& stomach pain. Physically, she also feels very sick. She has visited a govt. hospital for 1 to 2 times, but doctors told her that she needs to take food \& medicine. Nobody buys medicine for her \& she is unable to afford it himself. When asked about her suggestion, she simple wants to have a place to live \& simply meals to eat.

\subsection{Case: 3}

Case-3 respondent's is 65 years old women lives with her family and migrated from Cumillah at Karom Ali Bosti since 15 years. She lives in a joint family with her husband and only son, daughter in law and two grandchildren. She has no educational background but she can signature. She has total four rooms and they are the owner of this room except land. They use two rooms and get 3,000 tk from other two rooms. They use separate kitchen but share toilet with their neighbors. The toilet is totally unhygienic and unhealthy. The room is also tin shaded surrounded by tin and floor is damped and not well ventilated. The respondent's family use supply water by payment 2 tk per pots and drinks this water without boiled. The respondents and her husband is sailor of cigarette and battle leaf. The respondent's son is a private car driver and her daughter-in-law is a made servant. The family income is approximately 10000 tk per month and they save an amount from it. The respondent is not a healthy person and suffering from different types of old age related disease such as joint pain, severe food allergy and severe dementia etc. She goes to govt. hospital and consults with doctor and buy medicine 800-1000 tk per month. She spends her leisure time by gossiping with neighbors and grandchildren and tries to say prayers regularly does not watches television.

\subsection{Case: 4}

Case-4, respondents is 60 years plus old separated women lives in Karom Bli bosti, Agargaon, Dhaka for 30 years. She is illiterate. She \& her son lives in small room. Her son still depends on her income due to lack of proper opportunities. The respondent worked her whole life as maid servant to be able to care for her children. Still now she has to work for food. She spends her leisure time by gossiping with neighbors, watching TV of neighbors \& praying. Sometimes her son tries to do something for family. Her daughter takes care of her if she is sick. But her daughter can't afford to stay longer. Usually relatives occasionally provide economic support \& in times of emergency. She is suffering from depression \& insomnia. She said that she faces problems like depression, irritation \& isolation due to her inabilities to get proper support. When asked about her suggestion, Ayesha simply wants to have a place to live $\&$ simple meals to eat. She also wishes to get buy a bus for her son so that he can earn \& contribute to the family. 


\subsection{Case: 5}

A seventy years old women lives at Karam Ali Bosti at Agargaon Dhaka almost ten years and migrate from Mymensing. Her husband passed away very shortly after they got married. She knows how to write her name. She has a son, but after getting married he got himself separated from her mother. Now she lives with her nephew. Currently, her family consists of three members. After the death of her husband, she works as a maid servant. Her monthly income is in between 2000 to 2500 BDT. She has to spend her whole income in medical sector. Her nephew bears the expenditure of her food and clothes. They have electricity that's why she enjoys Television and they are facilitated with fans in their house. They have not any water and gas support. She uses "katcha latrin". In their house, they use Balcony as a Kitchen. The respondent's is an Asthma patient. She concerns most for her back pain and in addition she sees hazy. She thinks that Government should provide her old age allowance. She passes her leisure period by gossiping with the neighbors. Besides, most of the time she feels very lonely.

\subsection{Case: 6}

There was an eighty five years old woman who was born in Mymensing. She has three sons and two daughters. All of them are got married to their local area and don't bother to communicate with her. But she lives with her grandson and grandson's wife in a slum named Karam Ali Slum, Agargaon. She is permanent at this slum. She has left no opinions in her family. She and the other people of this slum seldom enjoy any urban facilities. The respondent is a street beggar and earns BDT. 3000 per month. She cannot continue begging due to her physical inability. She takes her meal three times in a day. She has to give her income to her grandson. She gets old age allowance 300 tk per month but it's not sufficient for her expenditure. The dwellers of this slum have not any water supply, gas and electricity facility and she uses "katcha latrin". She has some health problem. If any day she got ill, she won't able to get proper treatment due to poverty. After all, she thinks she leads almost a suitable life. But she worries about her future. She passes her leisure period by gossiping with the neighbors. Besides, most of the time she feels very lonely.

\subsection{Case: 7}

Case-7, respondent's is 60 years plus destitute elderly woman lives in company ghat (Pool par), near Kamrangir char, Dhaka. She is illiterate woman and lives with her son, daughter-in-law and grandchild since three years in the slum. They accommodate together in a bamboo and tin shade room at one bed soil made floor with electricity facilities. They use combine kitchen in open place and hanging type bamboo made toilet. They take supply water from WASA and boiled before drinking, but there is no option to purify or filter. Her son is only earning member of this family from a small fruit shop with limited income approximately 3000/4000 taka per month. She took microcredit from local broker for expanding her son's business and her treatment purposes just 2 years ago. She looks physically healthy, but she has some health problems including piles, chronic acidity problem and burning pain, multiple joints pain. Sometimes she cannot sleep well due to depression and thinking and future. She goes to doctor only in case emergency and went to visit doctor last month. And that time she borrowed 2000 taka for treatment purposes. She cooks combine with other neighbors. She is temporary resident of this slum. She is marginally happy regarding this social and economic condition. She feels lonely and most of the time she spends her time in room, because she cannot understand neighbor's local languages. She participates in decision making.

\subsection{Case: 8}

Case-8, respondents is 65 years old widow women lives in Aagergaon, Korom Ali'r Bosti (slum) Dhaka. She is illiterate and lives with her daughter-in-law and grandchild. They accommodate together in a bamboo and tin shade room at one bed soil made floor with electricity facilities. They use combine kitchen in open place and hanging type bamboo made toilet. They take supply water from WASA. Her daughter-in-law is only earning member of this family by working in household activities with limited income approximately 3000/4000 taka per month. She looks physically unhealthy; she has some health problems including goiter, dementia and multiple joints pain. If she feels pain, then she takes only painkiller from local pharmacy. She goes to doctor only in case emergency. Most of the time she spends her time in room. She cannot participates in decision making. But her daughter-in-law is very cooperative towards her.

\subsection{Case: 9}

A widow women age is 70 years old lives in Agargaon, Korom Ali'r Bosti (slum) Dhaka since 1971. She is illiterate woman and lives with her son, daughter-in-law and grandchild. They accommodate together in a bamboo and tin shade room at one bed soil made floor with electricity facilities. They use combine kitchen in open place and hanging type bamboo made toilet. They take supply water from WASA. Her son is only earning member of this family and he is a rickshaw puller with limited income almost 4000 taka per month. She looks physically healthy, but she has some health problems including chronic kidney disease, multiple joints pain. She always faces health related problem but does not go to the 
hospital or health complex due to the shortage of money. Sometimes she cannot sleep well due to depression and thinking and future. She cooks combine with other neighbors. Most of the time she spends her time with her grandchildren and neighbors. She participates in decision making.

\subsection{Case: 10}

Mrs. Shahanaj begum 62 years old divorced woman lives Aagergaon, Korom Ali'r Bosti (slum) Dhaka. She is illiterate woman and lives with her sister's sons, son's wife and her grandchild since Five years in the slum. They accommodate together in a bamboo and tin shade room at one bed soil made floor with electricity facilities and its rent is 2000 taka per month. They use combine kitchen in open place and hanging type bamboo made toilet. They take supply water from WASA but there is no option to purify or filter. Her sister's sons is only earning member and his income is approximately 8000 taka per month. She looks physically healthy and she has no chronic diseases. Sometimes she cannot sleep well due to depression and thinking for future. She goes to doctor only in case emergency. She cooks for her family and takes care of them. She is temporary resident of this slum. She is marginally happy regarding this social and economic condition. Most of the time she spends her time in room, because she has no child. She participates in decision making.

\subsection{Case: 11}

She was sixty five years old widow women lives Korom Ali Bosti (slum) area in Agargaon of Dhaka city for one year. She lives in a join family with her eight sons and two married daughters. There are two rooms with electricity facility. They sleep in two rooms and cook in a corner of this room. Their monthly income is 10000 taka which an efficient amount for their family. She passed her leisure time by watching TV, gossiping with neighbors and family members. They can use supply water which is provided by Dhaka WASA. They have no standard toilet and bathroom. There are only two toilets for every five family. She has not a healthful kitchen for making their meals. They don't have proper medical support. When they faced illness, they just go to the local pharmacy, take the medicine. They can't go to hospital, because of their economic crisis.

\subsection{Case: 12}

She is 62 years old separated women lives at Korom Ali Bosti (slum) area in Agargaon of Dhaka city for 35 years. She came from Barisal. She was born in Dhaka city. But she lives in a joint family consisting of six members. She works in an institution of decoration and earns 2500 taka per month. She is only one person who is an income person. There is only one room, where all members sleep at night. She reports that they can't get privacy which is a great problem to them. As the total income of his family is so low, so it is hardly possible to meet the basic needs of the family. Where she lives that room is built by the bamboo fancy and roof is built by the tin. They have no kitchen room and cook in their bed room. They get electricity facility but there is no television and electric fan. There is KACHA LATRIN which is used by two or three family's members in this slum. They collect water from WASA. They do not get any facility from Govt. like as VGF, old age allowance and so on. She goes to governmental hospital 2-3 times in month. She gets her treatment cost from donation by neighbors. She passed her time by sleeping, gossiping with neighbors. She has no any rights to take decision in her family matter.

\section{Discussion}

\subsection{Living Condition}

The general objective of the study is living condition of the elderly woman in the slum area of Dhaka city. Living condition of the slum area is not hygienic for health. All of the houses are built by the bamboo and roof is built by the tin. Most of the family members sleep in one room. Because of this they face a major problem which is privacy. There are children, grandsons, daughter in low in the room. Most of the family has no television in the room but electricity is available in here. Because of this, they cannot bear electricity or other's bill. There is a toilet which is used two or three family members. This is not good for their health. Drinking water is so much unhygienic for their health. They collect water from WASA. But this is not pure drinking water. They do not boil water and drink this which is not good for their health. They cannot remove this problem, because of their financial crisis. They are not conscious about their worse situation. Outsides of their house are unclear and dirty. As a result of this dirtiness, children are affected by multiple chronic diseases.

\subsection{Socio-Economic Condition}

A study we do hereby chosen 12 older women as sample. All respondents are above 60 years old. Most of the respondents are so much poor and live below the poverty line. Economic condition is very poor. Elderly women's ages, their level of education, last professional status, present marital status, number of their living children, and number of 
dependent children and so on. Again, their past and present income status and economic status of the elderly women's are also so much poor. All of them are bigger or made servant. They are classified as cooking for the family, tidying and cleaning household things, washing clothes, nursing the sick members of the family, and supervision and caretaker of grandchildren. Their monthly income is very low. Most of the respondents said that, primarily they have to depend on self-income from work. Their monthly income very much depends on their physical ability. They live hand to mouth. If any day, they got ill, they don't have the ability to go for treatment. Most of the occasion, they don't have medical support due to the poverty. Their vulnerable economic condition demands governmental support and various types of allowance.

\subsection{Health Condition}

Most of the respondents are suffering from many health problems including back pain, joint pain, cough and respiratory problems, loneliness, dementia, depression \& insomnia and so on. Proper nutrition is a challenge for their movement is getting restricted day by day. They use kacha latrine, which so much dangerous for their health. So that they face various kinds of diseases like as diahorria, malaria, dehydration and so on. Many of older persons are absolutely afraid of their future and do not know what steps to take in the year to come. In the face of fighting for their own life, they have no time to think of her mental conditions. Receiving no asset from their own family is very common among the respondents. They can't go to hospital or take drugs because of their weak economic condition. So they do not get proper or minimum medical facilities. They are unable to get their all of basic human needs due to their financial condition. The respondents cannot fulfill their daily nutrition as per their needs. Most of the respondents are dependent on other person.

\subsection{Educational Status}

The level of education of the elderly women in slum area has been situated in the research. The level of education is so poor. Most of them are illiterate. But a few of them can sing their name. Most of their children are illiterate. They have no interest in education. Most of the parents cannot make a right situation to give their children proper education just because of their awareness, consciousness, and their economic condition. The Govt. also indifferent for their education. Govt. cannot provide them a proper influence to get them educational institution. Most of the NGO's hardly trying motivate them to go educational institute. But the slum dwellers seem that, earning penny is more important rather than the education. For this reason they sent their child for work. These scenarios create new problems like child labor, anti-social activities etc.

\section{Conclusion}

The housing structures in the slums are temporary with no proper planning, and there is overcrowding, poor sanitation, and insecurity. Unemployment is high, and the majority of residents are involved in petty trading or casual labor. Given that these settlements are considered illegal, there is some reluctance by the authorities to provide services such as schools, roads, and healthcare facilities. Most of the respondents are illiterate. In Bangladesh, now a day, widows are considered as a burden in the family. Once a woman is widowed, she is then, in most cases, loses her right to have access to resources left by her husband which may be distributed among the family members as per hereditary law or to an assigned male relative. The government and all the general people should be awarded to come forward to help all the older women in slum area, then they can get rid of this curse and they can improve their living and socio-economic condition. If we take necessary steps then they can also improve their environmental condition and can save themselves from chronic, infectious disease.

\section{Compliance with ethical standards}

\section{Disclosure of conflict of interest}

No conflict of interest.

\section{Statement of informed consent}

Informed consent was obtained from all individual participants included in the study.

\section{References}

[1] BER. Bangladesh economic Review, Economic Adviser's Wing, Finance Division, Ministry of Finance, Government of the People's Republic of Bangladesh, Dhaka. 2007. 
[2] Alamgir et al. assessing the livelihood of slum dwellers in Dhaka city. J. Bangladesh Agril. Univ. 2009; 7(2): 373380.

[3] Islam et al. A Future Journey to the Elderly Support in Bangladesh. Hindawi Publishing Corporation, Journal of Anthropology. 2012; Article ID 752521, 6

[4] Rahman. Preparing for an elderly population, Rahman K M M. The Daily Star: Tuesday. 4 October 2011.

[5] Bangladesh Demographics Profile (BDP). 2013.

[6] Jesmin, Ingman. SOCIAL SUPPORTS FOR OLDER ADULTS IN BANGLADESH. The Journal of Aging in Emerging Economies. December. 2011; 74-78.

[7] Rahman KMM, Tareque MI, Munsur AM, Rahman MM. Elderly Abuse: Causes and Determinants in Rural Naogan District of Bangladesh". Journal of Population and Social Studies. 2010; 19(1): 25-36.

[8] Rahman MM, Tareque MI, Rahman KMM, Islam TM. Dimension of Population Ageing in Bangladesh", Middle East Journal of Age and Ageing. 2007; 4(5): 17-22.

[9] Munsur AM, Tareque MI, Rahman KMM. Determinants of Living Arrangement, Health Status and Abuse among Elderly Women: A Study of Rural Naogaon District, Bangladesh. Journal of International Women's studies. 2010; 11(4): 162-176.

[10] Carr C. Protecting Women's Safety in Slums. Search Light South Asia. 21 March 2012.

[11] Ferdous $\mathrm{T}$ et al. The multidimensional background of malnutrition among rural older individuals in Bangladesh - a challenge for the Millennium Development Goal. Public Health Nutrition, Submitted. 1 July 2008.

[12] UN-HABITAT. WOMEN, SLUMS AND URBANISATION. UN-HABITAT, State of the World Cities 2006/7 (Nairobi: UN-HABITAT, 2006).

[13] Akter T. Migration and living conditions in urban slums: implications for food security. 2009. 